\title{
Sustainability of energy use in Estonian settlements and regions
}

\author{
H. Hallemaa ${ }^{1}$, H. Vitsur ${ }^{2}$, T. Oja ${ }^{1} \&$ Ü. Mander ${ }^{1}$ \\ ${ }^{1}$ Institute of Geography, University of Tartu, Estonia \\ ${ }^{2}$ Ministry of Economic Affairs and Communications, Tallinn, Estonia
}

\begin{abstract}
Energy use and the sustainability and economic use thereof are the most essential questions for development, especially for economic development in each country. The effective use of energy has also been the focus of public debate in Estonia since the restoration of independence in 1991. On the one hand, Estonia has a relatively extensive supply of energy resources. On the other hand, energy use is generally not very economical and sustainable. This paper characterizes the main aspects of the development of sustainable and effective energy use in each sector of society in Estonia based on the classification of settlements and development units. We have performed emergy and exergy analyses of society in cities, counties and regions. The concept of emergy and exergy has been used in simplified and very general terms. The rate of use of renewable energy generally remains low, but is relatively higher in the southern and central part of Estonia. However, the rate of the use of wood for heat production in cities and counties and in Estonia as a whole has increased in the last decade. The average emergy rate for the whole country (0.109) is significantly lower than the average for most counties (0.12-0.71), except for the oil-shale region of Ida-Viru County (0.009). It is also relatively low in the capital city of Tallinn (0.080). The northern and north-eastern part of the country (including Tallinn) is remarkably less sustainable than the rest of the country. One of the biggest energy users and at the same time one of the most inefficient/uneconomical energy users is car transport, especially in the cities.
\end{abstract}

Keywords: car transport, cities, counties, emergy, energy system, exergy, sustainability of energy use, regions. 


\section{Introduction}

\subsection{Aims and objectives of study}

The article presents the results of the joint research carried out from 2004-2006. The aims and objectives of this study are: (1) to analyse energy use and the sustainability of the Estonian energy system and its characteristics and developments; (2) to analyse the regional differences in energy use and in the energy system in Estonia and between the internal regions and cities of Estonia; (3) to characterize the tendencies and point out measures for the development of sustainable and effective energy use in each sector of society in Estonia, based on the classification of the specified settlements and development units; (4) to perform emergy and exergy analyses of society in the cities and other development units and calculate respective indices; (5) to describe regional differences, characterize the tendencies and point out measures to make car transport more efficient/economical; (6) to study, describe and outline ideas and a design perspective for the development and changes in the future of the Energy System of Estonia on several development levels.

\subsection{The Republic of Estonia and units of its administrative system}

The Republic of Estonia is a relatively small country in the northeast of Europe, which regained its independence in 1991, joined NATO in March 2004 and the $\mathrm{EU}$ on the $1^{\text {st }}$ of May 2004. The process of rebuilding and developing Estonia's economy, institutional structure and society has been taking place for a little longer than fifteen years. As we have stated in previous articles [1], the territorial objects related to regional and local development and development policy development units - in Estonia are all units of the Estonian administrative system. As of the $1^{\text {st }}$ of January 2006, Estonia has 15 counties and 231 local administrations, including 32 towns and cities and 199 rural communities. Settlement units without the status of local administrations in Estonia are divided into urban communities in cities and 4607 rural communities: towns within parishes (5), townships (1), large villages (173) and villages (4428) (by the $1^{\text {st }}$ of January 2003) [1]. The administrative reform of Estonia is presently being designed and planned. One idea is to distinguish four prospective administrative regions. These have been taken as development regions to present research results for this paper.

\subsection{Theoretical approaches and bases for emergy and exergy analyses as methods in ecological energetics}

Emergy and exergy have been developed as complementary goal functions. By definition, emergy is the solar energy directly and indirectly required to generate a flow or storage. Exergy is a property of a system that measures the maximum work that can be extracted from a system when it moves towards the thermodynamic equilibrium with a reference state [2]. The concepts of emergy and exergy have been developed by Odum [3-7], Jørgensen et al. [8], Patten [9], 
Brown and Herendeen [10], Tiezzi et al. [11] and Zhou et al. [12]. This concept has been used for several practical reasons and applications [7, 13, 14]. Estersväg and Melnik have performed an exergy analysis of Norwegian society [15], and Estersväg has compared different societies based on society exergy analyses [16]. Energy hierarchy analyses and energetic zonation, like that of Taipei metropolitan region of Taiwan performed by Huang et al. [17], can be interesting and promising.

\section{Materials and methods}

\subsection{Emergy and exergy analyses of the Estonian energy system}

On the one hand, Estonia has a relatively extensive supply of energy resources. Oil shale (kukersite) is the main local primary energy source in Estonia (58\% of the total). It is mainly used to produce electricity (96\%). Oil shale is the second largest resource in heat production (22\%) after imported natural gas $(26 \%)$. However, it makes up only $7 \%$ of final consumption, being outstripped by imported engine fuel (54\%) and wood $(22 \%)$ [18]. On the other hand, the efficiency of energy use is very low and generally not sustainable in the long term.

We have performed emergy and exergy analyses of society in the cities and regions of Estonia. In this paper we describe and compare energy use and sustainability in Estonian settlements and cities and in counties and regions. At this time the counties act in energy use as backgrounds of cities and county centres (and this is how they have been considered in the analysis). The following types of settlements and research units have been distinguished: (1) Tallinn as the capital city and centre of agglomeration (TLN), (2) the agglomeration of Tallinn (TLN + rest of Harju County), (3) the large industrialized cities Narva (NAR), Kohtla-Järve (KJ) and Sillamäe (SIL), (4) other large cities Tartu (TRT) and Pärnu (PÄR), (5) county centres, (6) other settlements, (7) counties (backgrounds of cities), (8) EU NUTS 3 regions [18]: Northern (N), North-Eastern (NE), Central (C); Western (W), and Southern (S) Estonia, and (9) development regions.

\subsection{Data and materials for research}

For this study we used basic data from the Statistical Office of Estonia, the Ministry of Economic Affairs and Communications of Estonia, the Estonian Motor Vehicle Registration Centre (data about car traffic in 2002-2006) and local administrations. Some basic data for research and overall calculations was picked up from official publications $[18,19]$ and from the statistical database and regional development database (1991-2004) [20] of the Estonian Statistical Office. The regional data about the production and consumption of energy and fuel was taken from statistical annual accounting forms "Energy and Fuel" and its summaries by counties and cities for the period 1996-2004. We obtained the data about declared agricultural lands from the field register [21] and supported 
fields from the register of agricultural support [22] of the Estonian Agricultural Registers and Information Board. We also used the results of previous studies on this topic by the Institute of Geography of the University of Tartu [1, 23-26] and the Faculty of Power Engineering of Tallinn University of Technology.

Based on the data available in the Estonian Statistical Office [18-20], Primary Energy Consumption (PEC) was summated as follows:

$$
\begin{gathered}
\text { PEC }=\text { Consumption of coal }+ \text { oil shale }+ \text { milled peat }+ \text { sod peat }+ \text { firewood }+ \\
\text { wood chips }+ \text { wood waste }+ \text { natural gas }+ \text { liquefied gas }+ \text { heavy fuel oil }+ \\
\text { light fuel oil }+ \text { diesel }+ \text { motor gasoline }+ \text { aviation gasoline },
\end{gathered}
$$

where $P E C$ - total and specific energy in GJ or TJ and GJ per capita.

For the calculation of the Primary Energy Consumption with Imported Energy ( $\left.\boldsymbol{P E C}_{\mathbf{I}+\mathbf{E}-)}\right)$, we consider classical primary energy consumption $(P E C)$, but also take into consideration "imported" electricity and heat (used energy from other regions of Estonia), and subtract "exported" electricity and heat (energy, sold and transported to other regions of Estonia):

$$
\begin{aligned}
& P E C I+E-=P E C+\text { "imported" electricity + "imported" heat - "exported" } \\
& \text { electricity - "exported" heat }
\end{aligned}
$$

where $P E C_{I+E-}$ - total and specific energy in GJ or TJ and GJ per capita.

For the calculation of Renewable Energy Consumption (REC) we were only able to use firewood, wood chips and wood wastes, about which regional consumption statistics are available. Unfortunately we were unable to use data concerning the regional division of biogas (total for Estonia in 2004: $108 \mathrm{TJ}$, in $200021 \mathrm{TJ}$ and in 1996 only $8 \mathrm{TJ}$ ) and hydro-electric and wind energy (total by Estonia in $2004108 \mathrm{TJ}$, in $200021 \mathrm{TJ}$ and in 1996 only 8 TJ) [18]. Renewable Energy Consumption has been calculated as follows:

$$
R E C=\text { Consumption of firewood }+ \text { wood chips }+ \text { wood wastes }
$$

where $R E C$ - total and specific energy in GJ or TJ and GJ per capita.

Final Energy Consumption (FEC) comprises energy that is received and consumed after conversion into other forms of energy (fuel, electricity, heat). Final consumption excludes the use of energy for non-energy purposes, selfconsumption by power plants and losses [18, 19, 20]. Final Energy Consumption is the sum of the following:

$$
F E C_{\Sigma}=F E C_{f}+F E C_{e}+F E C_{h},
$$

where $F E C_{\Sigma}-$ Final Energy Consumption, total; $F E C_{f}-\mathrm{FEC}$, fuel; $F E C_{e}-\mathrm{FEC}$, electricity; $F E C_{h}-$ FEC, heat; (all in GJ or TJ and GJ per capita).

For analysing and characterizing the dynamics of car transport, we use the index:

$$
I_{\text {car }}=\text { number of cars / 1,000 inhabitants, }
$$

where the number of cars was calculated as of the end of the year (31.12). 
In all calculations of index $I_{c a r}$, the number of inhabitants in the current year has been taken as the de facto population size of the beginning of the next year. For practical reasons the number of inhabitants in 2005 was considered as de facto population size on 01.01.2006. In energy analysis per capita we used the mean annual population size of the current year.

\subsection{Emergy rate as the rate of environmental sustainability of an energy system}

We have used the concept of emergy and exergy analysis in simplified and very general terms.

The Emergy or Rate of Emergy is defined as follows:

$$
E m=R E C / P E C,
$$

where $E m$ - Emergy; REC - Renewable Energy Consumption; PEC - Primary Energy Consumption.

Emergy shows the ecological sustainability and efficiency of a society or the society's energy system. From this index we can see how great a proportion of energy production and consumption comes from materials that do not raise the entropy of systems [3-9].

\subsection{Exergy and efficiency rates as indices of the efficiency of an energy system}

The Exergy or Rate of Exergy is the relationship between final energy consumption (output) and used primary energy (input), or the percentage of final energy consumption from all used primary energy, this also in very general terms. We calculated this rate as follows:

$$
E x=F E C_{\Sigma} / P E C,
$$

where $E x-$ Exergy; $F E C_{\Sigma}-$ Final Energy Consumption, total; $P E C$ - Primary Energy Consumption.

The Efficiency or Rate of Efficiency is the relationship between final energy consumption (output) and used primary energy together with "imported" energy (input), or the percentage of final energy consumption from all used primary energy together with "imported" energy. We calculated this rate as follows:

$$
E f=F E C_{\Sigma} / P E C_{I+E-},
$$

where $E f$ - Efficiency; $F E C_{\Sigma}-$ Final Energy Consumption, total; $P E C_{I+E-}-$ Primary Energy Consumption, in which we have also taken into consideration "imported" electricity and heat and have subtracted "exported" electricity and heat.

At the same time, exergy is a measure of the energy or energetic sustainability and efficiency of a society or that society's energy system. It shows how great a proportion of energy input goes into the final output of the system. It also characterizes the system's overall efficiency. 
In our paper, efficiency was calculated as the efficiency of the real energy system of society together with all adjustments. Thus the rate of efficiency directly shows how rational a region's energy system is.

\section{Results and discussion}

\subsection{Energy resources, primary energy input and final energy output in Estonian regions}

There are extremely great differences in the character and sustainability of energy use between settlements and regions in Estonia (Table 1).

Table 1: $\quad$ Primary energy input (energy consumption) and final energy output (final energy consumption) in Estonian NUTS 3 regions and cities in 2004 (GJ per capita). For abbreviations of energy parameters, NUTS 3 regions and cities, see text.

\begin{tabular}{|l|cccccccccccc|}
\hline & EST & N & NE & S & W & C & TLN NAR & KJ & SIL TRT PÄR \\
\hline PEC & 170 & 84 & 807 & 63 & 63 & 93 & 89 & 1632 & 471 & 115 & 41 & 46 \\
PEC $_{\text {I+E- }}$ & 166 & 111 & 652 & 71 & 75 & 107 & 121 & 1181 & 517 & 101 & 52 & 65 \\
REC & 19 & 10 & 7 & 29 & 21 & 36 & 7 & 0 & 0 & 0 & 9 & 7 \\
FEC $_{\Sigma}$ & 90 & 101 & 107 & 67 & 69 & 105 & 107 & 105 & 98 & 52 & 48 & 67 \\
$\boldsymbol{F E C}_{\boldsymbol{f}}$ & 45 & 44 & 27 & 44 & 45 & 74 & 45 & 9 & 17 & 9 & 19 & 30 \\
$\boldsymbol{F E C}_{\boldsymbol{e}}$ & 20 & 26 & 42 & 8 & 9 & 12 & 29 & 62 & 32 & 16 & 8 & 11 \\
$\boldsymbol{F E C}_{\boldsymbol{h}}$ & 25 & 31 & 38 & 16 & 15 & 18 & 32 & 34 & 49 & 28 & 21 & 25 \\
\hline
\end{tabular}

On the one hand, oil-shale based electrical energy production in north-eastern Estonia supplies the rest of Estonia with energy. Therefore the PEC value (GJ per capita) in NE Estonia and the cities of Narva and Kohtla-Järve is considerably higher than in other counties and cities. One can also see that the primary energy input without secondary energy flows $\left(\mathrm{PEC}_{\mathrm{I}+\mathrm{E}-}\right)$ in the cities (Tallinn, Tartu, and Pärnu) is lower than final energy consumption. On the other hand, north-eastern Estonia and the capital city do not use renewable energy sources. In contrast, that ratio is highest in marginal regions in the south and west of the country. The FEC values show a significant concentration of final energy consumption in the northern and north-eastern parts of Estonia. Accordingly, these regions cannot be considered sustainable. In contrast, Tartu, Pärnu, and most counties outside of northern and north-eastern Estonia show much more sustainable energy consumption.

\subsection{The emergy rate of Estonia's energy system}

The results of the emergy analysis of Estonia's energy system by regions, counties, cities and county-centres are presented in Fig. 1. This is very much related to the results given in Table 1. The rate of use of renewable energy generally remains low, being relatively higher in the southern and central parts of 
Estonia. However, the rate of use of wood for heat production in cities and in counties and in Estonia as a whole has increased in the last decade. The average emergy rate of the whole country $(0.109)$ is significantly lower than in most counties (except for Ida-Viru County: 0.009). It is also extremely low in Tallinn $(0.080)$. The relative importance of renewable energy is great and the emergy rate is highest in Valga (0.706), Viljandi (0.568), Võru (0.533), Jõgeva (0.528) and Järva (0.506) counties.

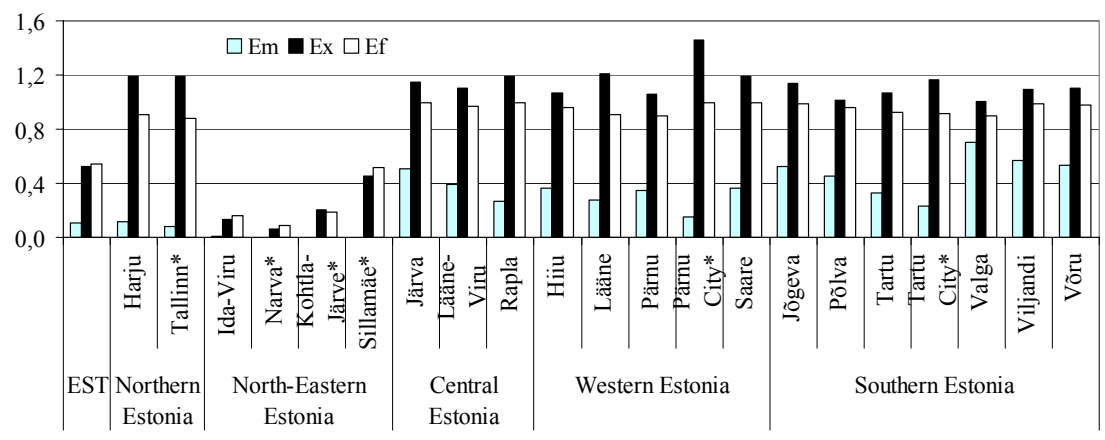

Figure 1: $\quad$ Emergy (Em), exergy (Ex) and efficiency (Ef) indexes in Estonia's counties (NUTS 3 regions) and cities in 2004.

\subsection{The exergy rate of Estonia's energy system}

The results of the exergy analysis of Estonia's energy system by regions, counties, cities and county-centres are also presented in Fig. 1. As in the case of emergy values, exergy and efficiency rates are closely related to the data in Table 1. There are regions that produce for the whole of Estonia (north-eastern Estonia) and counties that consume this service. Thus in general, all of the rest of Estonia excluding the Ida-Viru region itself consumes the electricity produced in this area. In comparison with other countries, wind and hydroelectric power production is developing very slowly outside the main energy production region in north-eastern Estonia. However, there are plans for the construction of biomass-based CHP (Combined Heat and Power) plants in several towns. The idea of the construction of several small nuclear power plants, which has recently been debated in some political circles, will hopefully never be realised.

\subsection{Car transport and its dynamics in the Estonian regions}

One of the biggest energy users and at the same time one of the most inefficient/uneconomical energy users is car transport, especially in the cities. The total number of cars and the index $\mathrm{I}_{\text {car }}$ has increased during the last decade, especially in cities and county centres (Fig. 2).

Although the number of cars is increasing year by year, gasoline consumption has generally remained constant during the last 15 years. The total number of cars at the end of 2002 was 486,182. In 2003 it was 522,776, in 2004 562,199, and in 2005585,175 , which makes 359 cars per 1,000 inhabitants in 2002, 387 in 
2003, 417 in 2004 and 434 in 2005. The consumption dynamics of motor gasoline in Estonia in thousands of tons per year was as follows: $1991-463$, 1992 - 228, 1995 - 247, 1996 - 280, 2000 - 306, 2001 - 335, $2002-311,2003$ -306 , and $2004-287[18,19]$. At the same time, the consumption of diesel oil (together with gas oil) has also increased somewhat over the last 15 years: (1991 - 676), 1992 - 413, 1995 - 375, 1996 - 408, 2000 - 450, 2001 - 492, 2002 $570,2003-592 \& 2004-608$ thousand tons per year [18, 19]. These are positive trends and show that new cars are more effective and more environmentally friendly, and probably the amount of kilometres per car has decreased. The same picture can be seen in the regions, counties and cities of Estonia. However, the regional differences in the car index remain significantly high. The road systems of the cities must be developed and the level of public transport must be increased in order to make urban transport more effective and environmentally sustainable.

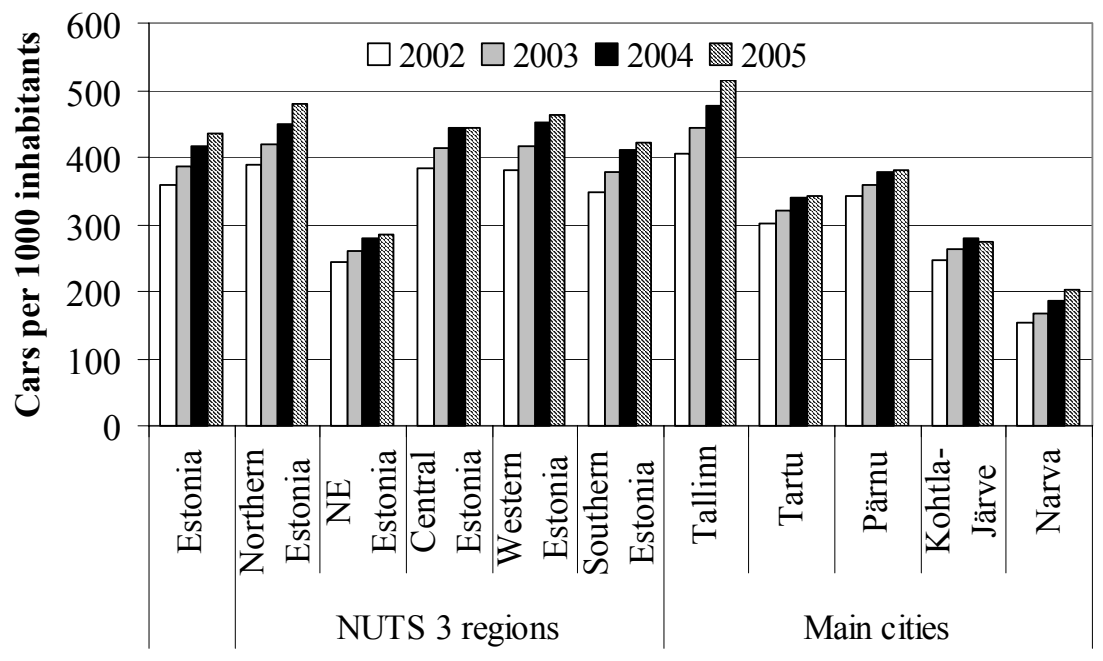

Figure 2: Dynamics of the car index (cars per 1,000 inhabitants) in Estonian regions in 2002-2005.

\subsection{Perspectives on the energy system in Estonia}

In Estonia, strategic development documents and policies in the area of energy economy are elaborated both by Government and Parliament [27, 28], against the background of the adoption of a Common Energy Policy and the design of perspective developments discussed also in the European Union and by the European Commission [29].

One of the most promising fields and spheres of energy production for Estonia will be biomass energy (energy forests, rape, grain, straw, dung, etc.) and biogas. There is great potential for this sphere of future agriculture in Estonia. In 2005, more than 380,000 ha of agricultural land was out of production (of the total of 1,219,780 ha declared in 2004: [21]). In 2005, 
agricultural subsidies covered 837,098 ha [22]). By our calculations, it would be possible to produce approximately $47,000 \mathrm{TJ}$ of external energy from this perspective, which is $41.8 \%$ of total final energy consumption in 2004 . Wetlands are a challenging opportunity for sustainable development and energy production [23]. In the new Estonian Rural Development Strategy for 2007-2013 [30], renewable energy production is considered to be one of the priorities and fields for agricultural subsidies for this period. At the same time, it launches and supports the establishment of new jobs in rural areas. For the year 2020 there are possibilities to increase the percentage of renewable energy in Estonia's total energy balance by up to $25 \%$. Nuclear energy could yield approximately $25 \%$ of energy consumption. These developments will reduce the role of fossil fuels (especially oil shale) in the energy balance by about $25-50 \%$. Thanks to these important steps, emergy, exergy and efficiency rates will increase significantly. Finally, it will result in an improvement in the ecological and energetic sustainability of the energy system in Estonia

\section{Conclusions}

In Estonia, the effective use of energy has been the focus of public debate since the country regained its independence in 1991. There are remarkable differences in the character and level of sustainability of energy use between the settlements and regions of Estonia. The rate of use of renewable energy (the emergy rate) generally remains low, being relatively higher in the southern and central parts of Estonia. However, the rate of use of wood for heat production in cities has increased in the last decade. Regarding the exergy rate, there are regions that produce for the whole country (north-eastern Estonia) and counties that use these services. In general, the rest of the country consumes power production from the oil-shale region in Ida-Viru County. One of the greatest energy users and at the same time one of the most inefficient/uneconomical energy users is car transport, especially in the cities. The road systems in the cities must be developed and the level of public transport increased in order to make urban transport more effective and environmentally sustainable.

In terms of energy sustainability parameters, northern and north-eastern Estonia and the capital city Tallinn could not be considered sustainable. In contrast, Tartu, Pärnu, and most counties outside northern and north-eastern Estonia demonstrate a much more sustainable energy policy.

The development and adoption of changes in the Common Energy Policy are being discussed and planned in both Estonia and the European Union.

\section{Acknowledgement}

This study was supported by Target Funding Project No. 0182534s03 of the Ministry of Education and Science of Estonia. 


\section{References}

[1] Hallemaa H., Regional Development and Development Policy in Estonia and European Community. Economical Policy of Estonia in European Union, Tallinn Technical University: Tallinn \& University of Tartu; Tartu, pp. 42 - 62, 1996. (In Estonian, summary in English)

[2] Bastianoni, S. \& Marcettini, N., Emergy/exergy ratio as a measure of the level of organization of systems. Ecological Modelling, 99, pp. 33-40, 1997.

[3] Odum, H.T., Environment, Power, and Society. Wiley-Interscience: New York, 331 pp., 1971.

[4] Odum, H.T., System Ecology. John Wiley: New York, NY, 644 pp, 1983.

[5] Odum, H.T., Environmental accounting, emergy and decision making. John Wiley: New York, 1996.

[6] Odum, H.T., Self-organization, transformity, and information. Science, 242, pp. 1132-1139, 1998.

[7] Odum, H.T., Emergy evaluation of an OTEC electrical power system. Energy, 25, pp. 389-393, 2000.

[8] Jørgensen, S.E., Nielsen, S.N. \& Mejer, H., Emergy, environ, exergy and ecological modelling. Ecological Modelling, 77, pp. 99-109, 1995.

[9] Patten, B.C., Network integration of ecological extremal principles: exergy, emergy, power, ascendency and indirect effects. Ecological Modelling, 79, pp. 75-84, 1995.

[10] Brown, M.T. \& Herendeen, R.A., Embodied energy analysis and EMERGY analysis: a comparative view. Ecological Economics, 19, pp. 219-235, 1996.

[11] Tiezzi, E., Bastianoni, S. \& Marchettini, N., Environmental cost and steady state: the problem of adiabaticity in the emergy value. Ecological Modelling, 90, pp. 33-37, 1996.

[12] Zhou, J., Ma, S. \& Hinman, G.W., Ecological exergy analysis: a new method for ecological energetics research. Ecological Modelling, 84, pp. 291-303, 1996.

[13] Martin, J.F., Emergy valuation of diversions of river water to marshes in the Mississippi River Delta. Ecological Engineering, 18, pp. 265-286, 2002.

[14] Bastianoni, S., Marcettini, N., Panzieri, M. \& Tiezzi, E., Sustainability assessment of a farm in the Chianti area (Italy). Journal of Cleaner Production, 9, pp. 365-373, 2001.

[15] Estersväg, I.S. \& Melnik, M., Exergy analysis of the Norwegian society. Energy, 25, pp. 957-973, 2000.

[16] Estersväg, I.S., Society exergy analysis: a comparison of different societies. Energy, 26, pp. 253-270, 2001.

[17] Huang, S.-L., Lai, H.-Y. \& Lee, C.-L., Energy hierarchy and urban landscape system. Landscape and Urban Planning, 53, pp. 145-161, 2001.

[18] Energy Balance 1991-2004: Yearbooks, Statistical Office of Estonia: Tallinn, 1992-2005. 
[19] Estonian Statistical Yearbooks 1991-2004, Statistical Office of Estonia: Tallinn, 1992-2005.

[20] Fuel consumption by county 1991-2004, Statistics Estonia, Regional Development Database, Economy, Energy; Statistical Office of Estonia: Tallinn. www.stat.ee, http://pub.stat.ee

[21] Field register; Estonian Agricultural Registers and Information Board: Tartu. www.pria.ee, http://eng.pria.ee

[22] Register of agricultural support; Estonian Agricultural Registers and Information Board: Tartu. www.pria.ee, http://eng.pria.ee

[23] Denafas, G., Revoldas, V., Zaliauskiene, A., Bendere, R., Kudrenickis, I., Mander, Ü., Oja, T., Sergeeva, L. \& Esipenko, A., Environmental consequences of the use of biomass and combustible wastes in the Baltic region. Latvian Journal of Physics and Technical Sciences, 2, pp. 24-44, 2002.

[24] Kull, A., Post, R. \& Selg, V., Conclusions on Renewable Energy Resources, Their Potential and Economic Efficiency. Possible Energy Sector Trends in Estonia, Context of Climate Change, Tallinn, pp. 105$127,1999$.

[25] Mander, Ü., Strandberg, M., Mauring, T. \& Remm, K., Wetlands as an essential basis for sustainable development: the Estonian case. Villacampa, Y., Brebbia, C.A. \& Uso, J.-L., (eds). Ecosystems and Sustainable Development III, WIT Press: Southampton and Boston, pp. 459-467, 2001.

[26] Mander, Ü., Oja, T., Hallemaa, H., Kull, A., Bendere, R., Kudrenickis, I., Sergeeva, L. \& Denafas, G., Environmental pollution analysis of energy production and consumption in the Baltic region. Tiezzi, E., Brebbia, C.A. \& Uso, J.L., (eds). Ecosystems and Sustainable Development IV, WIT Press: Southampton and Boston, pp. 835-845, 2003.

[27] Estonian Electricity Economy Development Plan for 2005-2015: adopted by ordinance of Government of Estonia No 5 from 03.01.2006. Tallinn, RTL, 18.01.2006, 7, 134, eRT. (In Estonian).

[28] Long Term Public Fuel and Energy Sector Development Plan until 2015: Adopted by Riigikogu 15.12.2004; Ministry of Economic Affairs and Communications: Tallinn, www.mkm.ee (RTI, 23.12.2004, 88, 601, eRT (In Estonian)).

[29] Doing more with less - Green Paper on energy efficiency; European Commission, Directorate - General for Energy and Transport, 2005. www.europa.eu.int/comm/energy/efficiency/doc/2005_06_green_paper_boo k engl.pdf

[30] Estonian Rural Development Strategy 2007-2013: Draft; Estonian Ministry of Agriculture: Tallinn, 26.03.2006. www.agri.ee/mas (In Estonian) 